УДК 330.101

\title{
ДОСЛІДЖЕННЯ СКЛАДОВИХ ЕКОНОМІЧНОЇ БЕЗПЕКИ УКРАЇНИ ДЛЯ СТАЛОГО РОЗВИТКУ ДЕРЖАВИ
}

\author{
Ейтутіс Г.Д., д.е.н., професор (ДУІТ) \\ Попова Д.В., магістрант (КНУ ім. Т.Г.Шевченка)
}

В статті розглянуто актуальні методи оцінки сучасного стану економічної безпеки України. Також розкрита сутність нагальних проблем економічної безпеки Украӥни та надання пропозицій щзодо подолання кризових явищ сучасного господарства держави. Проаналізовано шляхи подолання кризових станів різних галузей виробництва для сталого розвитку та економічного зростання держави в умовах інтеграчії країни до світових економічних організачій.

Ключові слова: економічна безпека, органи держсавного управління, економічні показники, індикатори економічної безпеки.

\section{ИССЛЕДОВАНИЕ СОСТАВЛЯЮЩИХ ЭКОНОМИЧЕСКОЙ БЕЗОПАСНОСТИ УКРАИНЫ ДЛЯ ПОСТОЯННОГО РАЗВИТИЯ ГОСУДАРСТВА}

\author{
Эйтутис Г.Д., о.э.н., профессор (ГУИТ) \\ Попова Д.В., магистрант (КНУ им. Т.Г.Шевченко)
}

В статье рассмотрены актуальные методы оченки современного состояния экономической безопасности Украины. Также раскрыта сущность актуальных проблем экономической безопасности Украинь и представлены предложения по преодолению кризисных явлений современного хозяйства страны. Проанализированы пути преодоления кризисных состояний различных отраслей производства для устойчивого развития и экономического роста государства в условиях интеграции страны в мировых экономических организаций.

Ключевые слова: экономическая безопасность, органы государственного управления, экономические показатели, индикаторы экономической безопасности.

\section{RESEARCH OF UKRAINE'S ECONOMIC SECURITY COMPONENTS FOR THE STABLE DEVELOPMENT OF THE STATE}

\section{Eitutis H., Ph.D., Professor (State University of Infrastructure and Technology) Popova D., master's student (Taras Shevchenko Kyiv National University)}

The article considers the innovative methods of estimation and analysis of the current economic security situation in Ukraine. The nature of current problems of economic security of State is also disclosed and proposals are presented for overcoming the crisis phenomena of the modern develeping economy of the country. This article reflects the institutional features of the economic security ensuring of the State in the face of instability and the emergence of new threats associated with the cyclical nature of the economy. The ways of overcoming the crisis conditions of various branches of production for the sustainable development and

(C) Ейтутіс Г.Д.,

Попова Д.В.

Вісник економіки транспорту і промисловості № 62, 2018 
economic growth of the state in the condition of integration of the country in the world economic markets and organizations are analyzed. The purpose of the article is to reveal the urgent issues of Ukraine's economic security and provide the solution of the crisis of the modern state economy. It is important to note that the state's economic security also serves as a criterion for the effectiveness (efficiency) of the state's economic policy. Allocation of national economic interest as one of the most important in the structure of national interests of the country is the basis for the effective sustainable development of economic system. National economic security is understood as the protection of the economy from internal and external adverse factors that interfere with normal functioning of the internal reproduction process, undermine the standard of living of the population and thereby cause increased social tension in society, as well as the threat to the state itself. Among the top priority issues of the economic security is monitoring and assessment of the level of threats to priority national interests, and therefore their interdependence: the calculation of total potential, the disclosure of laws in the system of "priorities of national interests - threats".

Key words: economic security, state administration institutes, economic indicators, indicators of economic security.

\section{Постановка}

Економічна безпека будь-якої країни, однієї сторони, є важливою складовою системи національної безпеки, що формує захист національних інтересів, з іншої - $\epsilon$ безпосередньою умовою дотримання i реалізації національних інтересів щодо забезпечення фінансування, формування доходів та витрат тощо.

Економічна безпека в першу чергу сприяе створенню надійної та забезпеченої всіма необхідними засобами держави, захищеності національнодержавних інтересів у сфері економіки.

При цьому основним критерієм економічної безпеки є здатність економіки країни зберігати та підвищувати стійкість до внутрішніх та зовнішніх загроз.

Підвищення економічної безпеки регіону залежить від міри державної підтримки й розробки державних програм регіонального розвитку, а також від розміщення державних замовлень на поставку продукції для потреб усієї країни.

В умовах України зміцненню економічної безпеки регіонів перешкоджають об'єктивні чинники, зокрема, диференціація регіонів за економіко-географічним розташуванням, природно-ресурсним потенціалом, структурою населення, галузевою спеціалізацією,

фінансовою забезпеченістю, типом соціальноекономічного розвитку тощо.

Важливо зазначити, що економічна безпека держави виступає i як критерій дієвості (ефективності) економічної політики держави. Виділення економічних національних інтересів як одних 3 найважливіших в структурі національних інтересів країни $€$ основою ефективного сталого розвитку їі економічної системи.

Національна економічна безпека розуміється як захищеність економіки від внутрішніх i зовнішніх несприятливих факторів, які перешкоджають нормальному функціонуванню процесу внутрішнього відтворення, підривають досягнутий рівень життя населення і тим самим викликають підвищену соціальну напруженість в суспільстві, а також загрозу самій державі.

Аналіз останніх досліджень i публікацій. Питання різних аспектів економічної безпеки держави досить пильно та активно вивчається в національних наукових колах, зокрема такими вченими як Дікань В.Л. [2], Бернацкий П.Й. [3], Гуревич А. [4], Майданевич Ю.П. [4], Богма О.С. [6], Бойко Т.В [7], Левчук О.В. [8], Рєзнік O.M. [9]. 
Теоретико-методичні

засади формування системи економічної безпеки широко представлені в працях західних науковців, серед яких слід виділити наукову роботу Р.Хаусмана та Б.Клінгера [1].

Мета статті полягає в розкритті сутності нагальних проблем економічної безпеки України та надання пропозицій щодо подолання кризових явищ сучасного господарства держави.

Виклад основного матеріалу. У Законі України «Про основи національної безпеки України» визначено, що національна безпека України - це захищеність життєво важливих інтересів людини, громадянина, суспільства та держави, за якої забезпечуються сталий розвиток суспільства, сучасне виявлення, запобігання і нейтралізація реальних та потенційних загроз національним інтересам [10].

Що стосується законодавчого визначення поняття економічної безпеки України то воно міститься в Методичних рекомендаціях щодо розрахунків рівня економічної безпеки України, що затверджені в Наказі Міністерства економічного розвитку і торгівлі України від 29 жовтня 2013 року [11].

Відповідно до цих рекомендацій економічна безпека - це стан національної економіки, який дає змогу зберігати стійкість до внутрішніх та зовнішніх загроз, забезпечувати високу конкурентоспроможність у світовому економічному середовищі і характеризує здатність національної економіки до сталого та збалансованого зростання. В цілому ж, економічна безпека - це стан держави, за якого вона має можливість створювати і розвивати ефективні умови для перспективного розвитку та зростання добробуту громадян. Основним критерієм економічної безпеки країни вважається здатність ऑï економіки зберігати або, принаймні, швидко поновлювати рівень суспільного відтворення в умовах критичного зменшення (припинення) поставок ресурсів (товарів, послуг, технологій тощо) або кризових ситуацій внутрішнього чи зовнішнього характеру.

При аналізі економічної безпеки виділяються передусім три важливих складові [12]:

- економічна незалежність, що означає насамперед можливість здійснення державного контролю над національними ресурсами, спроможність використовувати національні конкурентні переваги для забезпечення рівноправної участі у міжнародній торгівлі;

- стійкість і стабільність національної економіки, що передбачає міцність i надійність усіх елементів економічної системи, захист усіх форм власності, створення гарантій для ефективної підприємницької діяльності, стримування дестабілізуючих факторів;

- здатність до саморозвитку i прогресу, тобто спроможність самостійно реалізовувати i захищати національні економічні інтереси, здійснювати постійну модернізацію виробництва, ефективну інвестиційну та інноваційну політику, розвивати інтелектуальний i трудовий потенціал країни.

Більшість дослідників економічної безпеки доходять висновку, що основними структурними елементами економічної безпеки, які необхідно застосувати при іiі аналізі на рівні держави, є такі [13]:

- сировинно-ресурсна безпека;

- енергетична безпека;

- фінансова безпека;

- соціальна безпека;

- інноваційно-технологічна

безпека;

- продовольча безпека;

- зовнішньоекономічна безпека.

Вважається, що економічна безпека - це свого роду забезпечення в довгостроковій перспективі таких систем показників як [14]:

1. Економічна незалежність (фінансова, сировинно-ресурсна, інноваційна тощо); 
2. Економічна стабільність (рівень розвитку, що гарантує відчуття безпеки сьогодні та в майбутньому);

3. Економічний

(інноваційно-інвестиційна реструктуризація, оздоровлення).

Такий підхід до трактування суті економічної безпеки (країни, регіону, підприємства) відображає іiі основне функціональне значення - збереження економічної самостійності та досягнутого рівня, а також підвищення конкурентоспроможності й розширення можливостей подальшого розвитку. Гарантом захисту національних економічних інтересів повинна виступати держава. Однак в Україні ще відсутні чітко визначені національні економічні інтереси, не сформовано їхню цілісну систему. Це дає змогу урядовцям різних рівнів виправдовувати свої дії, запевняючи, що вони повністю відповідають національним економічним інтересам.

Для створення цілісної системи національних, економічних інтересів та їх ефективного функціонування насамперед необхідно [13]: створити відповідну нормативну базу; проводити моніторинг національних економічних інтересів та їх моделювання; створити банк даних щодо національних економічних інтересів; забезпечити баланс національних економічних інтересів та їх гармонійне поєднання.

Серед першочергових проблем забезпечення економічної безпеки $\epsilon$ відстеження й оцінка рівня загроз пріоритетним національним інтересам, а отже їх взаємозалежність: розрахунок сумарного потенціалу, розкриття закономірності в системі «пріоритети національних інтересів - загрози» (Рис. 1).

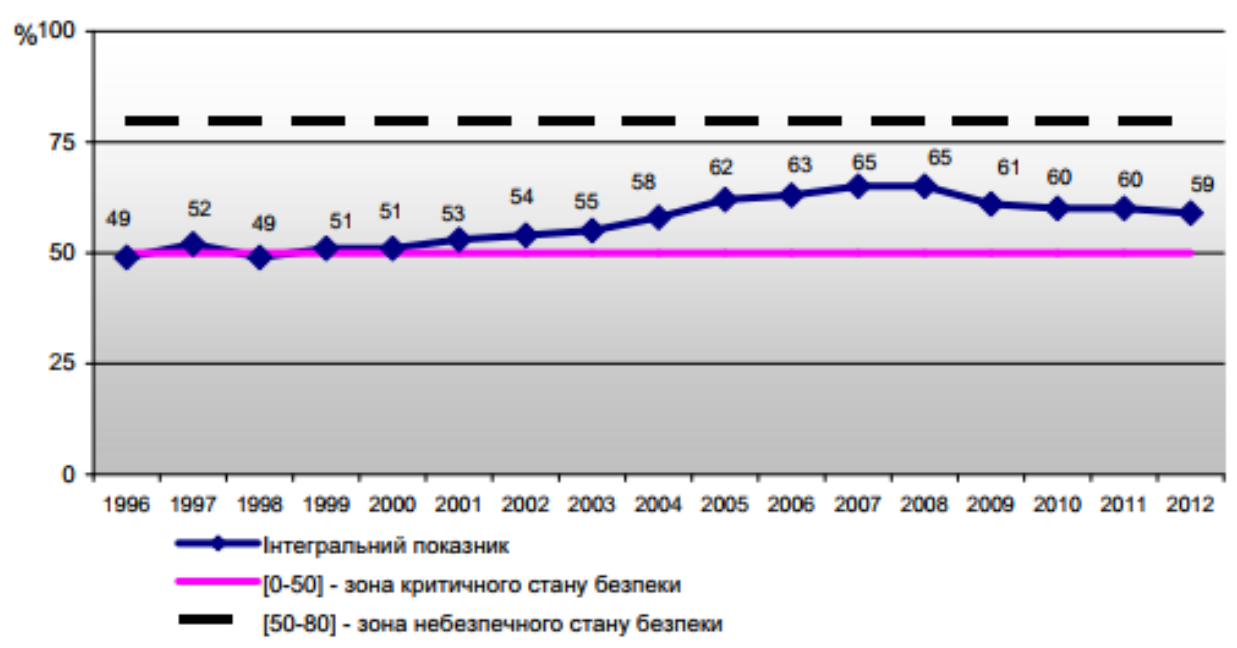

Рис. 1. Інтегральний показник економічної безпеки Украӥни (за даними Міністерства економічного розвитку і торгівлі України)[15]

Кожний індикатор має свій ваговий коефіцієнт, що вказує на ступінь внеску в забезпечення безпеки кожної складової. Стан економічної безпеки України оцінюється шляхом зіставлення розрахованих індикаторів безпеки 3 їх рубіжними значеннями. Наявність Значного відхилення від рубіжного значення свідчить про позитивний або негативний вплив на інтегральний рівень певної складової економічної безпеки.

Найбільш конкретне уявлення про основні складники економічної безпеки надано в Методиці розрахунку рівня економічної безпеки України, розробленій Міністерством економічного розвитку та торгівлі України, де складниками економічної безпеки є: макроекономічна, 
фінансова, інвестиційна, енергетична, зовнішньоекономічна, соціальна, продовольча та інші (Табл. 1) науково-технологічна, [11]. Розглянемо деякі з них детально.

Таблиияя 1

Ваговий коефіцієнт складових економічної безпеки

\begin{tabular}{|c|c|}
\hline Складові економічної безпеки & Значення вагового коефіцієнту \\
\hline 1 & 0,1005 \\
\hline Макроекономічна & 0,0769 \\
\hline Виробнича & 0,1127 \\
\hline Фінансова & 0,0939 \\
\hline Інвестиційна & 0,0901 \\
\hline Зовнішньоекономічна & 0,1183 \\
\hline Науково-технологічна & 0,0808 \\
\hline Соціальна & 0,0836 \\
\hline Демографічна & 0,1326 \\
\hline Енергетична & 0,1108 \\
\hline Продовольча & \\
\hline
\end{tabular}

Як бачимо 3 таблиці найбільший вплив на економічну безпеку справляють такі ії складові як енергетична, фінансова, науково-технологічна.

Разом 3 тим варто зазначити соціальну, демографічну та продовольчу складові, як елементи соціальної безпеки, винести 3 економічної системи до загального показника національної безпеки, збільшивши при цьому ваговий коефіцієнт інвестиційної та зовнішньоекономічної складових. При цьому незаперечним $є$ їх взаємозв'язок із економічною системою країни разом 3 екологічною, оборонною тощо.

За останніми даними в зоні критичного стану знаходиться макроекономічна $(43 \%)$ та науковотехнологічна (48\%) складові. Разом з тим переважна більшість складових рівня економічної безпекизнаходиться у зоні небезпечного стану безпеки (Рисунок 2).

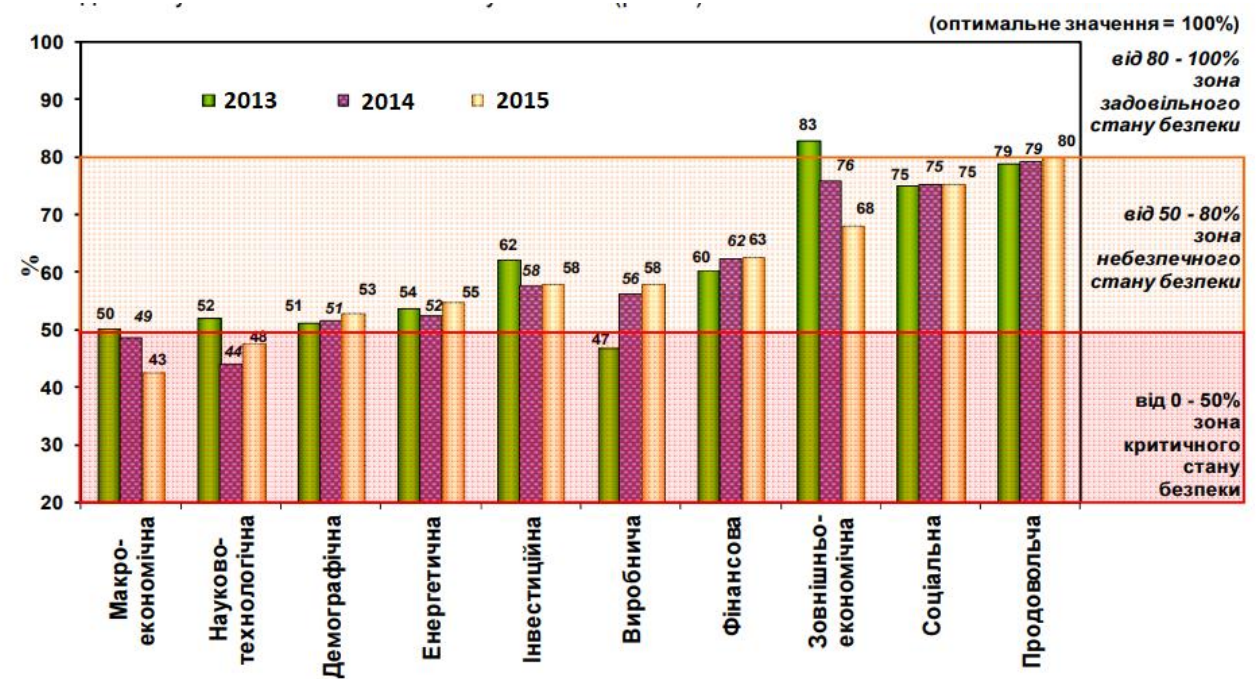

Рис. 2. Часткові індикатори складових економічної безпеки України (за даними Міністерства економічного розвитку і торгівлі України) [15] 
На межі критичного стану $\epsilon$ енергетична (55\%) та демографічна (53\%) складові безпеки. До негативних тенденцій варто віднести зменшення рівня зовнішньоекономічної безпеки та іiі переміщення із зони задовільного стану при значенні індикатора $83 \%$ у 2009 році до $68 \%$ у 2011, що показує наявність проблем в сфері міжнародного співробітництва. Підвищення економічної безпеки України залежить від можливості невідкладної реалізації принципово нової економічної моделі розвитку, каталізатором якої можна розглядати сучасну кризу. Має бути застосована всеохоплююча ревізія та сформовані плани консервації технологічних процесів та виробничих фондів, модернізувати які не має економічного сенсу. Принциповим $\epsilon$ розширення міжнародного співробітництва України для підвищення рівня інноваційності на основі випереджального залучення іноземного технологічного та інноваційного капіталу. Прогрес у відчутному збільшенні ВВП можливий лише на новій технологічній основі, розвантаженні ключових дисбалансів та досягненні інклюзивного розвитку (тобто підвищення рівня доходів для всіх категорій населення).

Разом 3 тим, державна політика України у сфері енергетики характеризується неузгодженістю економічних та політичних інтересів на різних рівнях управління. Так проблемами енергоефективності профільні комітети та відомства почали перейматися тільки 3 настанням політичної кризи та коливаннями валютних курсів. Не узгоджені питання диверсифікації постачання енергоресурсів на основі співпраці 3 такими країнами як Азербайджан, Казахстан, Туркменістан, Алжир, Іран, країни Перської затоки тощо.

Підвищення цін на енергоносії для населення здійснюється без врахування поточної ситуації, пов'язаної із падінням реальних доходів домогосподарств, а також відсутністю модернізації систем теплопостачання. Перелічені моменти не сприяють зміцненню економічної безпеки країни та породжують перекоси у перерозподілі грошових потоків, що генеруються у результаті реалізації енергоресурсів.

Тому коригування державної політики енергобезпеки має відбуватися шляхом узгодження національних інтересів і стратегіï євроінтеграції у розрізі таких напрямів [16]:

- добування та відновлення енергоресурсів: нарощування частки відновлювальних джерел енергії та заміщення традиційних;

- транспортування і розподіл: модернізація ГТС з метою нарощування та повного використання іiі потенціалу із залученням іноземного капіталу;

- використання: впровадження засад енергоефективності у всіх сферах споживання енергоресурсів шляхом залучення передових технологій та відповідної тарифної політики.

Висновок. На сьогодні численної кількості проблем в енергетичній, фінансовій, виробничій, макроекономічній, інвестиційно-інноваційній, соціальній, продовольчій, демографічній та зовнішньоекономічній сферах, які унеможливлюють стабільний соціальноекономічний розвиток України та призводять до зниження загального рівня національної економічної безпеки. Зазначене зумовлює необхідність розроблення та затвердження на державному рівні обгрунтованої Концепції економічної безпеки України, реалізація якої створить можливості ефективного захисту й реалізації національних економічних інтересів на основі цілеспрямованого впливу на існуючі загрози зовнішнього та внутрішнього походження.

Національна економічна безпека $\epsilon$ процесом забезпечення стійкого i безпечного розвитку економічної системи, при якому економіка здатна вирішувати такі завдання: забезпечення незалежності 
національної економіки, економічного суверенітету країни, iї енергетичної незалежності; ефективне задоволення матеріальних потреб особи, суспільства і держави; підтримка необхідного рівня соціальної та політичної стабільності суспільства; створення умов для гармонійного розвитку системи економічних відносин; підтримка необхідного рівня соціальної та політичної стабільності суспільства; ефективний захист внутрішніх і зовнішніх ринків; захист усіх форм власності; забезпечення стійкості розвитку економіки країни в умовах непередбаченого розриву міжнародних економічних зв'язків; забезпечення стійкості економіки в разі виникнення надзвичайних ситуацій природного i техногенного характеру, а також збройних конфліктів різного рівня; нейтралізація впливу на економіку кримінальних структур.

\section{ПЕРЕЛІК ВИКОРИСТАНИХ ДЖЕРЕЛ}

1. Hausmann R. The Structure of the Product Space and the Evolution of Comparative Advantage / R. Hausmann, B. Klinger. - Harvard University, 2007. - P.40.

2. Дикань В.Л. Украина в глобальной миросистеме: особенности и последствия государственной экономической политики / Дикань В.Л., Обруч А.В.. // Вісник економіки та транспорту. - 2017. - №59. - C. 11-19.

3. Бернацкий П.Й. Экономическая безопасность в системе национальногосударственнных интересов Украины / П.Й. Бернацкий. // Проблемы экономики. 2010. - №1. - C. 24-29.

4. Гуревич А. Экономическая безопасность Украины: лишнее зачеркнуть / A. Гуревич // ZN,UA [Електронний peсурс]. - Режим доступу: https://zn.ua/ECONOMICS/ekonomicheskaya _bezopasnost_ukrainy_lishnee_zacherknut.ht $\mathrm{ml}$.

5. Майданевич

Ю.П.
Ю.П. Майданевич С.Ю. Гагаев // Научные труды Южного филиала национального университета биоресурсов и природоиспользования Украины «Крымский агротехнологический университет». - 2012. - №143. - С. 145-149.

6. Богма О.С. Аналіз рівня економічної безпеки України за основними складовими / О.С. Богма // Науковий вісник Ужгородського національного університету. - 2016. - №8. - С. 11-14.

7. Бойко Т.В. Актуальні проблеми економічної безпеки України // Електронний ресурс / Т. В. Бойко. - Режим доступу: http://library.kr.ua/orhus/bojko.pdf .

8. Левчук О.В. Економічна безпека України в контексті глобалізацій них викликів / О.В. Левчук // Економіка i суспільство. - 2017. - №8. - С. 59-64.

9. Рєзнік О.М. Порівняльний аналіз сутності економічної безпеки України та країн Європейського Союзу / О.М. Рєзнік // Форум права. - 2015. - № 4. - С. 232-236.

10. ЗАКОН УКРАЇНИ "Про основи національної безпеки України"(Відомості Верховної Ради України (ВВР), 2003, № 39, ст.351). 2003 [Електронний ресурс]. Режим доступу: https://xn-80aagahqwyibe8an.com/ukrajiny-zakony/ zakon-ukrajini-pro-osnovi-natsionalnoji2003706.html

11. Наказ

Міністерства економічного розвитку і торгівлі України 29.10.2013 N 1277 МЕТОДИЧНІ РЕКОМЕНДАЦІї щодо розрахунку рівня економічної безпеки України [Електронний pecypc]. - Режим доступу: http://cct.com.ua/2013/29.10.2013_1277.htm.

12. Безуглова Ю.В. Проблемы формирования механизма экономической безопасности организации в современных условиях / Ю.В. Безуглова, Т.Н. Иголкина // Вестник Белгородского университета кооперации, экономики и права. - 2017. №2. - С. 93-106.

13. Зайцева І.Ю. Підвищення економічної безпеки автотранспортних підприємств в умовах розвитку недружніх Экономическая безопасность Украины / 
поглинань / I Ю. Зайцева. - Харків: УкрДАЗТ, 2009. - 357 с.

14. Ляшенко

O.

M.

Концептуалізація управління економічною безпекою підприємства : монографія / О. М. Ляшенко. - Луганськ : Вид-во СНУ ім. Володимира Даля, 2011. - 400 с.

15. Офіційний сайт Міністерства економічного розвитку і торгівлі України
[Електронний ресурс]. - Режим доступу : http://www.me.gov.ua.

16. Власюк Т.О. Стан і тенденції зовнішньоторговельної діяльності України: виклики для економічної безпеки та способи їх подолання / Т.О. Власюк // Стратегічні пріоритети. - 2015. - № 4(37). C. $48-58$.

DOI 10.18664/338.47:338.45.v\%vi\%i.133517

УДК 504:33(477/54)

\title{
ЕКОЛОГІЧНА СКЛАДОВА ЗАБЕЗПЕЧЕННЯ ЕКОНОМІЧНОЇ БЕЗПЕКИ РЕГІОНУ
}

\author{
Каменева Н.М., к.е.н., доцент, \\ Косич М.В., к.е.н., доцент, \\ Александрова О.Ю., ст. викладач (УкрДУЗТ)
}

Одною з найважливіших складових економічної безпеки регіону $є$ ї̈ екологічна безпека. У статті на прикладі Харківської області показано, щзо сьогодні є екологічні питання, що стають загрозою економічної безпеки країни в иілому та певного регіону зокрема. Тому екологічній складовій приділяється велика увага у державних документах з економічного розвитку, програмах національної безпеки та законах Украӥни. Харківщчина, як один $з$ найкрупніших промислових регіонів у країні, має екологічно несприятливу ситуацію. Але протягом останніх років ситуація змінилася на краще. Зроблено висновки про те, що необхідно розробити програму державного економічного стимулювання раціонального природокористування для збереження довкілля.

Ключові слова: економічна безпека, екологічна безпека, регіональна економіка, внутрішня та зовнішня безпека, природоохоронні заходи.

\section{ЭКОЛОГИЧЕСКАЯ СОСТАВЛЯЮЩАЯ ОБЕСПЕЧЕНИЯ ЭКОНОМИЧЕСКОЙ БЕЗОПАСНОСТИ РЕГИОНА}

\author{
Каменева Н.Н., К.э.н., доцент, \\ Косич М.В., к.э.н., доцент, \\ Александрова Е.Ю., ст. преподаватель (УкрГУЖТ)
}

Одной из важнейших составляющих экономической безопасности региона является ее экологическая безопасность. В статье на примере Харьковской области показано, что сегодня есть экологические вопросы, которые становятся угрозой экономической безопасности страны в целом и определенного региона в частности.

(C) Каменева Н.М.,

Косич М.В.,

Вісник економіки транспорту і промисловості № 62, 2018

Александрова О.Ю. 